\title{
Cutaneous Manifestations of Diabetes Mellitus and Prediabetes
}

\section{Manifestações Cutâneas da Diabetes Mellitus e Pré-Diabetes}

\author{
Maria Mendonça SANCHES $\rrbracket^{1}$, Ângela RODA 1 , Rita PIMENTA 1 , Paulo Leal FILIPE¹, João Pedro FREITAS ${ }^{1}$ \\ Acta Med Port 2019 Jun;32(6):459-465 - https://doi.org/10.20344/amp.10738
}

\begin{abstract}
Diabetes is a serious, chronic disease with a rising prevalence worldwide. Its complications are a major cause of morbidity and mortality and contribute substantially to health care costs. In this article the authors review the most common and sensitive skin manifestations that can be present on patients with diabetes and prediabetes. The prompt recognition of these frequently underestimated entities is extremely important as it may trigger not only an adequate metabolic evaluation but also a timely referral and appropriate treatment, minimizing the secondary effects of long-term diabetes and improving the prognosis of diabetic patients.
\end{abstract}

Keywords: Diabetes Complications; Diabetes Mellitus; Prediabetic State; Skin Diseases/etiology

\section{RESUMO}

A diabetes mellitus é uma doença crónica, com uma prevalência crescente a nível mundial. As complicações da diabetes são uma causa major de morbilidade e mortalidade, condicionando custos importantes na área da saúde. Neste artigo é efetuada uma revisão das manifestações cutâneas mais frequentes presentes em doentes com diabetes e pré-diabetes. O reconhecimento atempado destas entidades é fulcral, levando não só a uma avaliação atempada do perfil metabólico como a uma referenciação e tratamento precoces. Desta forma, é possível minimizar os efeitos secundários da diabetes a longo prazo, melhorando significativamente o prognóstico dos doentes.

Palavras-chave: Complicações da Diabetes; Diabetes Mellitus; Doenças da Pele/etiologia; Estado Pré-Diabético

\section{INTRODUCTION}

During the past decades diabetes mellitus (DM) epidemics escalated and became one of the most important worldwide health care challenges because of its associated morbidity and mortality. Epidemiological data suggest that type 2 diabetes mellitus is expanding at an epidemic rate and it has been estimated that by 2025 the number of patients with diabetes will reach $250-300$ million globally. ${ }^{1-4}$

During the course of their illness, cutaneous manifestations are seen in approximately $30 \%$ of diabetics. Some of these manifestations are related to insulin resistance which may even appear before the diagnosis of DM is confirmed. ${ }^{3,5}$

The prompt recognition of skin manifestations in patients with prediabetes or diabetes is extremely important as it may trigger not only an adequate metabolic evaluation but also a timely referral and treatment, minimizing the secondary effects of long-term diabetes and improving the prognosis of diabetic patients.

The objective of this article is to review the most frequent and specific skin manifestations of prediabetic and diabetic patients, which should be clearly recognized by any clinician.

\section{Epidemiology}

Worldwide, around 382 million individuals are diabetic, and $40 \%-50 \%$ of the global population is labelled at 'high risk' (i.e., prediabetes). ${ }^{2}$

Boyle et al reported that the annual diagnosed diabetes incidence will increase from about 8 cases per 1000 in 2008 to about 15 in 2050 in the United States (US). Assuming a low incidence and relatively high diabetes mortality, total diabetes prevalence is projected to increase from $14 \%$ in 2010 to $21 \%$ of the US adult population by 2050 . However, if the rise in diabetes incidence continues and the disease mortality remains low, prevalence will increase to $33 \%$ by 2050. A middle-ground scenario projects a prevalence of $25 \%$ to $28 \%$ by $2050 .^{3}$

\section{History}

Before the discovery of insulin, diabetes was merely considered a disease of the carbohydrate metabolism. This simplistic idea was based on the fact that the main cause of death of diabetic patients was diabetic coma. Up to that time, the only therapy available for children with diabetes was a form of starvation diet that enabled these patients to gain a one- or two-year survival. ${ }^{6,7}$

With the discovery of insulin in 1921 by Banting and Best the scenery changed dramatically. The lifetime of a diabetic patient increased and death from coma became rare..$^{6-8}$

\section{CUTANEOUS MANIFESTATION OF VASCULAR ABNORMALITIES IN DIABETES MELLITUS}

The vascular abnormalities are a major cause of morbidity and mortality in diabetic patients. Both large and small blood vessels are pathologically involved in diabetes, contributing to some of the most unfortunate complications, such as nephropathy, retinopathy and diabetic foot. ${ }^{9,10}$

Diabetic microangiopathy is characterized by the proliferation of endothelial cells, loss of pericytes and deposition

1. Clínica Universitária de Dermatologia. Hospital de Santa Maria. Lisbon. Portugal.

$\triangle$ Autor correspondente: Maria Mendonça Sanches. mariasanxes@hotmail.com

Recebido: 29 de abril de 2018 - Aceite: 14 de dezembro de 2018| Copyright @ Ordem dos Médicos 2019 
of periodic acid-Schiff positive material over the basement membrane of arterioles, capillaries and venules ${ }^{11}$. Oxidative stress is one of the most important causes of endothelial lesion, inducing leucocyte adhesion, altered coagulation and inflammation. ${ }^{11,12}$ Although thickening of the basal membrane is consistently found in diabetic patients, this finding is not pathognomonic and can be found in other diseases such as in heart failure, myxedema, connective tissue diseases and is a normal process of aging. ${ }^{11,13}$

Macroangiopathy in diabetic patients evolves through different phases, such as endothelial dysfunction, low vessel wall elasticity and sclerosis. These changes lead to a deregulated cardiovascular autonomic function with loss of vessel wall elasticity, insufficiency of the peripheral circulation and impairment of the neuronal function. ${ }^{14,15}$ Currently, many studies have correlated diabetic polyneuropathy (DPN) with diabetic macroangiopathy, emphasizing the importance of vascular dysfunction, driven by metabolic change, as a cause of diabetic neuropathy. ${ }^{14,16,17}$

There is a clear relation between macrovascular and microvascular impairment in type 2 diabetes. Macrovascular damage together with microvascular change causes ischaemia and hypoxia in neural tissues because of disordered endothelial function, arterial stiffness, and stenosis. ${ }^{14,15,18}$

\section{Chronic ulcers and diabetic foot}

Chronic ulcers, including pressure ulcers and diabetic foot infections, are a major complication in diabetic patients, particularly in dependent elderly with altered consciousness. ${ }^{10,19}$ According to the diabetic foot study of the National Health Insurance Claims in Taiwan, more than $94 \%$ of DM patients with diabetic foot had associated foot infections in hospital care, and the rates of lower extremity amputation remained persistently high. ${ }^{20}$

The prompt recognition and diagnosis of diabetic foot is of major importance. In the presence of critical limb ischaemia, or in the presence of mild to severe ischaemia, revascularisation of the limb should be considered. In these patients a multidisciplinary approach, involving a vascular surgeon, endocrinologist, rehabilitation specialist, cast technician, shoe technician and a podiatrist is required. Secondary prevention is also mandatory and after wound healing, education, adequate offloading and frequent foot examinations should be carried out.

\section{Diabetic dermopathy}

Diabetic dermopathy (DD), a cutaneous marker of diabetic microangiopathy, is the most common cutaneous manifestation of diabetes mellitus seen more frequently in older patients, especially those older than 50 years, and those who have had DM for a longer period of time..$^{19,21,22}$ This is a subtle clinical sign, many times dismissed by patients and characterized by asymptomatic brown pigmented patches and macules and round or oval atrophic, depressed lesions over the pretibial areas. It has been proposed as an unfavourable association with three common diabetic microangiopathic complications, namely neuropathy, nephropathy and retinopathy as well as coronary artery disease. ${ }^{21-23}$

Although treatment for the cutaneous element of DD is neither recommended nor effective, the presence of this entity should prompt aggressive intervention to detect DM, minimizing the development of further complications. ${ }^{22,24}$

\section{Rubeosis facei}

Rubeosis, also named rubeosis facei and rubeosis faciei diabeticorum is a common but often unnoticed clinical manifestation of DM, occurring in up to $59 \%$ of hospitalized patients with DM and is often a sign of suboptimal glycaemic control. ${ }^{25,26}$

The underlying mechanism is suggested to be diabetic microangiopathy, which results in dilatation of superficial veins. ${ }^{26,27}$ Therefore, these patients should be carefully evaluated, in order to exclude other coexisting microangiopathies, such as retinopathy or nephropathy. Strict glycaemic control is the mainstay of treatment for this manifestation. ${ }^{26}$

\section{Necrobiosis lipoidica}

Necrobiosis lipoidica (NL) is a chronic granulomatous disease of the dermis. ${ }^{28}$ It is mostly frequently seen in diabetic patients although it has been described in patients with sarcoidosis, inflammatory bowel disease, autoimmune thyroiditis, rheumatoid arthritis, monoclonal gammopathy, and otherwise healthy patients with normal glucose metabolism and no history of autoimmune diseases. ${ }^{29-31}$

The incidence of $\mathrm{NL}$ in people with diabetes is $0.3 \%$ to $1.2 \%{ }^{32}$ It precedes a diagnosis of diabetes in up to $14 \%$ of patients, is diagnosed simultaneously in up to $24 \%$, and appears after a diagnosis of diabetes in up to $62 \%{ }^{32}$

Although the aetiology is not clear, the most widely accepted theory is that microagiopathic changes and hypoxia play a significant important role in the pathogenesis of this disease. ${ }^{33-35}$

Lesions typically present over the pretibial area as well-circumscribed papules and nodules with active erythematous borders that slowly coalesce into plaques (Fig. 1). Initially these plaques contain a central area that appears red-brown, but later progresses to a yellow-brown discoloration. Telangiectasis can develop as a direct result of collagen degeneration occurring beneath the epidermis. ${ }^{28,32,35}$

Once the diagnosis is made it is crucial to monitor the lesions for signs of ulceration and treat aggressively to decrease the potential of malignant transformation into squamous cell carcinoma. ${ }^{36,37}$

Currently there are several off-label treatment options with varying results that can be offered to patients with NL. From these, surgery seems to be the less favourable and more challenging option since NL lesions can exhibit the Koebner phenomenon. ${ }^{28,35}$

\section{CUTANEOUS INFECTIONS IN DIABETES MELLITUS}

Amongst diabetic patients, the risk of developing various infections has been evaluated in an enormous amount of published studies. ${ }^{37-39}$ These patients also seem to have a 
higher risk of mortality when such infections occur and the numbers rise if concomitant cardiovascular disease is present. ${ }^{39}$ As such, all clinicians should promptly recognize these infections and initiate the correct therapy as soon as possible.

Altered immune function as well as diabetic neuropathy and altered circulation as previously described are well-recognized risk factors for the development of skin and soft tissue infections (SSTI). ${ }^{39,40}$ This risk seems to be higher in patients with a worse metabolic control and higher HbA1c levels. ${ }^{38}$

\section{Fungal infections - Onychomycosis and foot skin mycosis}

As previously mentioned, diabetic foot represents one of the most complex and serious complications in diabetic patients, sometime leading to limb amputation. ${ }^{10,19,20}$ Fungal infections are important contributors to the severity of the diabetic foot. ${ }^{41,42}$

According to Papine et al, diabetic patients have a significantly higher prevalence of both onychomycosis $(53.3 \%)$ and foot skin mycosis (46.7\%). In these patients Trichophyton rubrum and Trichophyton interdigitale were the most frequently isolated species. They stated that previous toe amputation was significantly associated with both skin and nail mycosis. ${ }^{41}$

Although fungal foot infections have a high burden of morbidity in diabetic patients, they are still extremely underestimated. In these patients a careful mycological examination of diabetic foot and an adequate treatment, tailored according to the fungal species involved is mandatory.

\section{Fungal infections - Balanoposthitis}

Balanitis is an inflammation of the glans penis, while posthitis implies inflammation of the prepuce. ${ }^{43,44}$ In uncir-

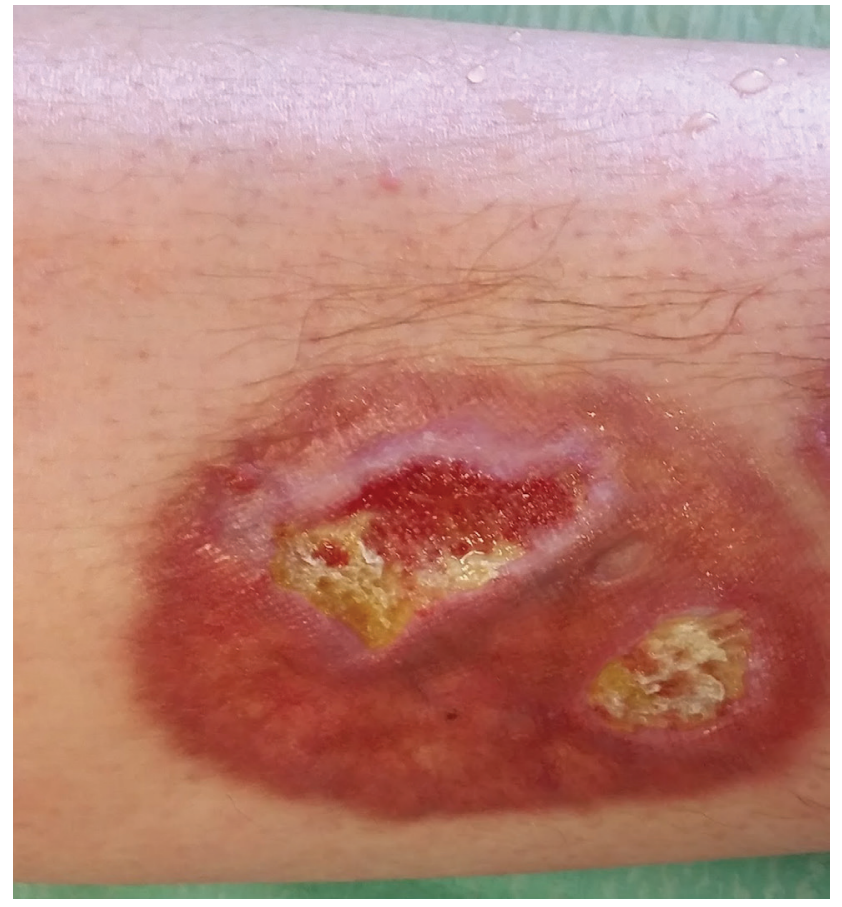

Figure 1 - Necrobiosis lipoidica: Ulcerated plaque over the pretibial area with active erythematous borders cumcised men, both areas are affected concurrently and the term balanoposthitis is used. The etiology of balanoposthitis in diabetes is usually infectious and the commonest pathogen involved is Candida albicans. ${ }^{43}$

While there are several different causes of balanoposthitis, underlying medical conditions such as uncontrolled diabetes have been associated with this diagnosis. ${ }^{43,44}$ The genital irritation prompts patients to seek medical evaluation, and at that point diabetes is diagnosed. Therefore, it is crucial for a clinician to recognize this entity and screen for diabetes in these patients and those who report "well-controlled diabetes" should be screened carefully for glycaemic variability and hyperglycaemia. ${ }^{43}$

Treatment sometimes is challenging as it not only relies on a good glycemic control but there is also an increased resistance of different species of Candida to various antifungal agents, recently documented in vitro. ${ }^{44}$ As such, management principles in diabetic balananoposthitis include maintaining perineal hygiene, correcting mechanical predisposing factors, achieving glycaemic control, and eradicating infection. ${ }^{43}$

\section{Bacterial infections - Skin and soft tissue infections}

Skin breakdown presented in diabetic patients provides an easy portal of entry for bacteria and the immune defects lead to an unfavourable response to the most common skin and soft tissue infection (SSTI) pathogens, the most frequent being Staphylococcus aureus. ${ }^{38}$

Suaya et al reported that when compared to non-diabetic ambulatory patients, those with DM seem to have more abscesses/cellulitis, decubitus ulcers, and surgical site infections. When looking at inpatients, the authors stated that patients with DM were more likely to have an SSTI-associated complication, with the highest complication rates for both groups among patients with decubitus ulcers. ${ }^{45}$

When analysing the most frequently involved pathogens, mild infections are mostly caused by Gram-positive cocci, with a prevalence of Staphylococcus aureus. For moderate infections, pyogenic Gram-positive cocci as well as Gram-negative bacteria are commonly implicated pathogens. In severe infections the aetiology is usually polymicrobial. ${ }^{46}$

Once the clinician suspects of an underlying skin infection, the next step is to determine the aetiology with the aim to undertake a rational and appropriate treatment. The most reliable method is to obtain a specimen of material from an infected lesion and to perform a bacterioscopic examination and culture. This is particularly important in diabetic patients since the prevalence of multi-drug-resistant organisms, especially methicilin-resistant Staphylococcus aureus is elevated and the initiation of the correct antibiotic regimen is critical due to their poorer clinical outcomes. ${ }^{38,45,46}$

\section{Bacterial infections - Erythrasma}

Erythrasma is a cutaneous disorder caused by a Gram-positive bacillus, Corynebacterium minutissimum, more prevalent in diabetic patients. ${ }^{47}$ It may be one of the early signs of type $2 \mathrm{DM}$, presenting before serum glucose levels become diagnostic. ${ }^{47}$ 
Initially, it is characterized by the presence of asymptomatic erythematous patches that later may become brownish in colour and appear slightly raised from the surrounding skin, with areas of central clearing. The lesions appear mostly in occluded intertriginous areas such as the axillae, inframammary areas, interspaces of the toes, intergluteal and crural folds. The differential diagnosis includes psoriasis, dermatophytosis, candidiasis and intertrigo, and methods for differentiating include Wood's light examination, bacterial and mycological cultures. ${ }^{47}$

Once the diagnosis is established, treatment should be promptly started. Oral, topical and/or adjunctive therapies are frequently used in the treatment of cutaneous erythrasma. ${ }^{47,48}$ Although there is no consensus on optimal treatment of this disease, the use of Erythromycin $250 \mathrm{mg}$ four times daily for 14 days seems to be the treatment of choice, with documented cure rates as high as $100 \% .{ }^{47}$ Recently, Greywal et al reported a series of nine patients with erythrasma successfully treated with mupirocin $2 \%$ ointment during 2 to 4 weeks. ${ }^{48}$ As such, further studies need to establish the role of topical monotherapy as a primary treatment alternative in these patients.

\section{OTHER SKIN FINDINGS IN DIABETES MELLITUS Acanthosis nigricans}

Frequently underestimated, acanthosis nigricans (AN) is commonly associated with insulin resistance in obese patients and can be an early indicator of DM. ${ }^{49-51}$ Although it is usually related with endocrine changes, it can also be an adverse effect of several medications or even malignant neoplastic conditions. ${ }^{49,51}$

Clinically, it is characterized by thickened, dark brown, velvety and papillomatous plaques, typically affecting intertriginous surfaces and neck (Fig. 2). These lesions are commonly asymptomatic although pruritus can sometimes be present. ${ }^{49}$

Even though there are no randomized controlled trials analysing treatment options in $\mathrm{AN}$, multiple case reports suggest improvement of the skin lesions with treatment of its underlying condition. ${ }^{51}$

The presence of $\mathrm{AN}$ is definitely a good predictor of metabolic disorders, including diabetes. ${ }^{49-51}$ Therefore, clinicians should be trained and aware of this clinical diagnosis as it could lead to an early recognition of an underlying disease, preventing its progression.

\section{Skin tags}

Skin tags (ST), also known as acrochordons or soft fibromas, are the most common fibroepithelial tumours of the skin. ${ }^{52,53}$ Clinically they are small, soft skin tumours often appearing over the lateral aspects of the neck, back, axilla, trunk and face..$^{1,52}$

In 1951 Touraine first suggested that ST were associated with DM and obesity. ${ }^{54}$ Currently, a positive correlation has been found between the total number of ST and mean fasting plasma glucose. Patients with more than 30 ST are at an increased risk of developing diabetes, particularly females with ST beneath their breasts. It is important to mention that hypertension, hyperlipidaemia, atherosclerosis and AN also appear at a much higher rate in this population. ${ }^{52}$

As such, ST may represent a cutaneous sign for metabolic syndrome and prediabetes or diabetes. Changing the life-style of these patients may have a beneficial role, which should be emphasized by health care professionals.

\section{Bullosis diabeticorum}

Bullosis diabeticorum (BD) or diabetic bulla is a noninflammatory blistering condition of unknown aetiology that occurs in about $0.5 \%$ of diabetics in the USA. ${ }^{55}$ The blisters are usually large and asymmetrical and commonly affect acral and distal skin of lower extremities. ${ }^{55,56}$

The diagnosis of BD involves skin biopsies with subsequent histopathologic examination and immunofluorescence in order to rule out other immune bullous disorders such as bullous pemphigoid, epidermolysis bullosa acquisita, traumatic blisters, bullae due to drug reactions, insect bites, and bullous SLE. ${ }^{56-58}$

Although spontaneous healing without scarring frequently occurs in a few weeks and the blisters should be left intact to serve as a sterile dressing, close monitoring for secondary bacterial infection or haemorrhage is warranted. ${ }^{56,58}$

It is worth mentioning that diabetic bulla may also appear in individuals with prediabetes. ${ }^{56}$ Therefore, the awareness of this diagnosis by clinicians is important as it may lead not only to an early diagnosis of diabetes but also prevent secondary skin infections when managing these patients.

\section{Granuloma annulare}

Granuloma annulare (GA) is a non-infectious granulomatous skin disease that can present with a wide range of cutaneous morphologies including localized, generalized, subcutaneous, macular or plaque appearance. ${ }^{59}$ Localized GA is the classic and most frequent variant described in the literature. The lesions are commonly found on the

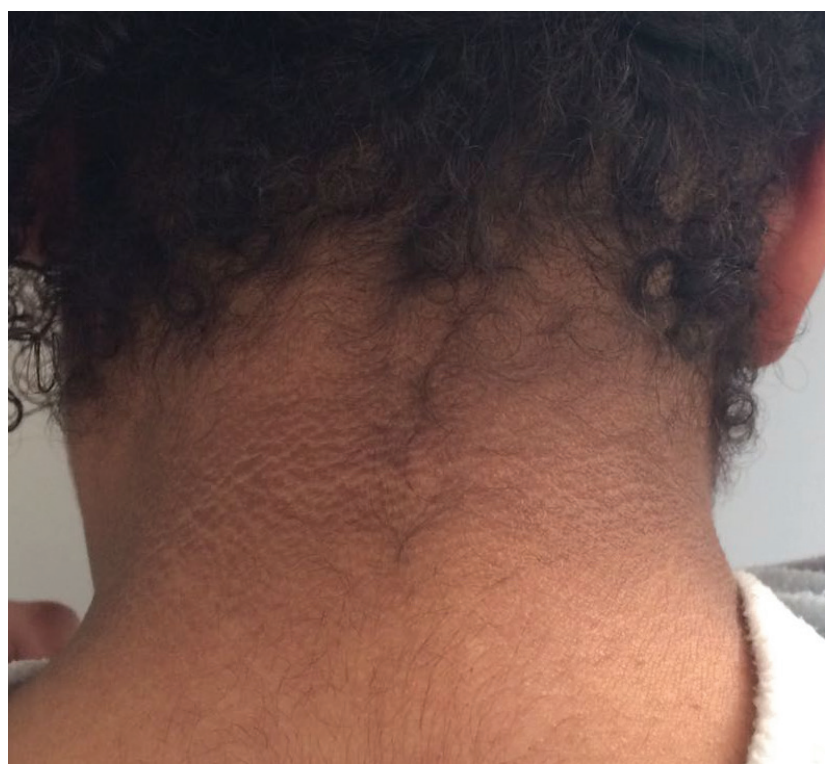

Figure 2 - Acanthosis nigricans: thickened, dark brown, velvety plaques on the posterior aspect of the neck 
dorsal aspects of hands and/or feet and are characterized by skin colour to erythematous papules arranged in annular configurations. ${ }^{59,60}$

Although the mechanism underlying development of GA is unknown, the study of Mempel et al describes a T cell response characterized by the combination of few skin-specific clones together with many nonspecific infiltrations, representing a particular type of granuloma composition. ${ }^{61}$

Several systemic associations with diabetes, thyroid disorders, lipid abnormalities, malignancy, and infection are described in the literature but not proven. ${ }^{60,61}$ Even though studies seem to have failed to report an association between GA and diabetes, screening for diabetes is advised for patients with this diagnosis. ${ }^{62-64}$

Current treatment options are divided into localized skin-directed therapies and systemic immunomodulatory or immunosuppressive therapies. The selection of a treatment modality should be based on cutaneous morphology, disease severity, comorbidities, consideration of potential side effects, prior treatments and patient preference. ${ }^{59,60}$

\section{Scleredema diabeticorum}

Scleredema diabeticorum (SDA) is characterized by severe permanent thickening of the skin of the posterior neck and upper back leading to a reduced range of motion. ${ }^{65-67}$ There can also be involvement of the hands and fingers, easily demonstrated by the 'prayer sign' (Fig. 3). ${ }^{66}$ Typically, the skin thickening develops over years and presents like peau d'orange, resulting in decreased sensation to pain and touch in the affected areas. ${ }^{65-68}$

This entity is primarily seen in individuals with long-standing diabetes. Although the prevalence of SDA among type 2 diabetic patients is approximately $2.5 \%$, more than $90 \%$ of those with this skin condition have diabetes. ${ }^{67}$

The disease pathophysiology is still not fully understood but proposed mechanisms are enhancement of collagen synthesis by fibroblasts and a reduced degradation of collagen with consequent reduction of skin elasticity. ${ }^{69}$

The early recognition of this rare disorder is important as it can cause a significant impairment of joint mobility over the years. Despite multiple therapy modalities described in the literature, SDA remains a difficult and resistant disease to treat. ${ }^{69-71}$

\section{Eruptive xanthomas}

Eruptive cutaneous xanthomas develop as a result of rapid intracellular and dermal deposition of lipids and are a major sign of hypertriglyceridemia. ${ }^{72}$ Clinically they are characterized by a sudden eruption of multiple erythematous-yellow dome-shaped papules, typically on the extensor surfaces of the extremities, buttocks, and hands. ${ }^{73}$ Severe hypertriglyceridemia can be caused by primary genetic mutations, secondary chronic diseases, or a combination of both. Uncontrolled diabetes mellitus is a well-documented risk factor. ${ }^{73}$

The treatment of eruptive xanthomas depends merely on the treatment of the primary disease. Systemic agents

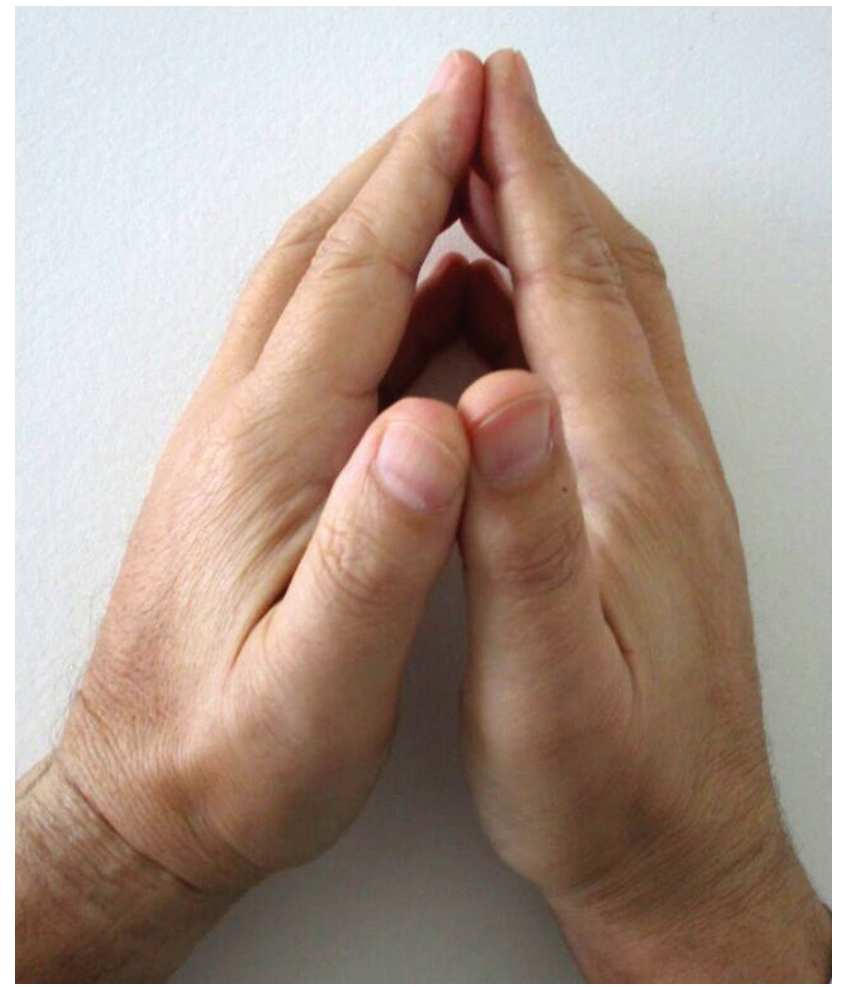

Figure 3 - Prayer sign: Hand stiffness resulting from flexion contractures of the fingers and thickened, tight, waxy skin

to treat hyperlipidemia may ameliorate cutaneous lesions. When there is no response to medical treatment, more invasive approaches may be needed, such as surgery, laser or cryosurgery. ${ }^{73}$

It is imperative that physicians are aware and recognize eruptive cutaneous xanthomas, as they are a reliable sign of severe hypertriglyceridemia, which contributes to the burden of cardiovascular disease and to the potentially fatal complications of acute pancreatitis. ${ }^{72,73}$

\section{CONCLUSION}

Diabetes mellitus is a widespread endocrine disease with severe impact on health care worldwide. Although frequently underestimated, the prompt diagnosis of skin manifestations related to the underlying mechanisms of a prediabetic or a diabetic state can have major clinical implications.

The correct diagnosis of these entities not only poses a diagnostic challenge to the clinician but also has a direct impact on treatment approaches, minimizing future comorbidities and complications which may involve other organs or systems.

The description and management of other dermatoses known to be associated with an increased incidence of diabetes, such as vitiligo, acquired perforating dermatoses, and lichen planus, or with an association with diabetes, such as psoriasis and diffuse alopecia as well as the drug reactions to anti-diabetic therapies are beyond the scope of this article.

\section{CONFLICTS OF INTEREST}

All authors report no conflict of interest. 


\section{FUNDING SOURCES}

This research received no specific grant from any funding agency in the public, commercial, or not-for-profit sectors.

\section{REFERENCES}

1. Bustan RS, Wasim D, Yderstraede KB, Bygum A. Specific skin signs as a cutaneous marker of diabetes mellitus and the prediabetic state - a systematic review. Dan Med J. 2017;64:A5316.

2. Boavida JM, Pereira M, Ayala M. A mortalidade por diabetes em Portugal. Acta Med Port. 2013;26:315-7.

3. González-Saldivar G. Skin manifestations of insulin resistance: from a biochemical stance to a clinical diagnosis and management. Dermatol Ther. 2017;7:37-51.

4. Boyle JP, Thompson TJ, Gregg EW, Barker LE, Williamson DF. Projection of the year 2050 burden of diabetes in the US adult population: dynamic modeling of incidence, mortality, and prediabetes prevalence. Popul Health Metr. 2010;8:29.

5. Huntley AC. The cutaneous manifestations diabetes mellitus. J Am Acad Dermatol. 1982;7:427-55.

6. Bliss M. The discovery of insulin: the inside story. Publ Am Inst Hist Pharm. 1997;16:93-9.

7. Alpert JS. An smazing dtory: the discovery of insulin. Am J Med. 2016;129:231-2.

8. Karamitsos DT. The story of insulin discovery. Diabetes Res Clin Pract. 2011;93:S2-8.

9. Freitas JP, Filipe PM, Rodrigo FG. Lipid peroxidation in type 2 normolipidemic diabetic patients. Diabetes Res Clin Pract. 1997;36:71-5.

10. Chao CY, Cheing GL. Microvascular dysfunction in diabetic foot disease and ulceration. Diabetes Metab Res Rev. 2009;25:604-14.

11. Camera A, Hopps E, Caimi G. Diabetic microangiopathy: physiopathological, clinical and therapeutic aspects. Minerva Endocrinol. 2007;32:209-29.

12. Lopes JP, Oliveira SM, Soares Fortunato J. Stress oxidativo e seus efeitos na insulino-resistência e disfunção das celulas Betapancreáticas: relação com as complicações da diabetes mellitus tipo 2 Acta Med Port. 2008;21:293-302.

13. McFadden PM, Berenson GS. Basement membrane changes in myocardial and skeletal muscle capillaries in myxedema. Circulation. 1972;45:808-14.

14. Ando A, Miyamoto M, Kotani K, Okada K, Nagasaka S, Ishibashi S. Cardio-ankle vascular index and indices of diabetic polyneuropathy in patients with type 2 diabetes. J Diabetes Res. 2017;2017:2810914.

15. Thrainsdottir S, Malik RA, Dahlin LB, Wiksell P, Eriksson KF, Rosén I, et al. Endoneurial capillary abnormalities presage deterioration of glucose tolerance and accompany peripheral neuropathy in man. Diabetes. 2003;52:2615-22.

16. Cameron NE, Eaton SE, Cotter MA, Tesfaye S. Vascular factors and metabolic interactions in the pathogenesis of diabetic neuropathy. Diabetologia. 2001;44:1973-88.

17. Cameron NE, Cotter MA. Metabolic and vascular factors in the pathogenesis of diabetic neuropathy. Diabetes. 1997;46:S31-7.

18. Choi SW, Yun WJ, Kim HY, Lee YH, Kweon SS, Rhee JA, et al. Association between albuminuria, carotid atherosclerosis, arterial stiffness, and peripheral arterial disease in Korean type 2 diabetic patients. Kidney Blood Press Res. 2010;33:111-8.

19. Tseng HW, Ger LP, Liang CK, Liou HH, Lam HC. High prevalence of cutaneous manifestations in the elderly with diabetes mellitus: an institution-based cross-sectional study in Taiwan. J Eur Acad Dermatol Venereol. 2015;29:1631-5.

20. Huang YY, Lin KD, Jiang YD, Chang CH, Chuang LM, Tai TY, et al. Diabetes-related kidney, eye, and foot disease in Taiwan: an analysis of the nationwide data for 2000-2009. J Formos Med Assoc. 2012;111:637-44.

21. Shemer A, Bergman R, Linn S, Kantor $Y$, Friedman-Birnbaum R. Diabetic dermopathy and internal complications in diabetes mellitus. Int J Dermatol. 1998;37:113-5.

22. Morgan AJ, Schwartz RA. Diabetic dermopathy: a subtle sign with grave implications. J Am Acad Dermatol. 2008;58:447-51.

23. Bauer MF, Levan NE, Frankel A, Bach J. Pigmented pretibial patches. A cutaneous manifestation of diabetes mellitus. Arch Dermatol. 1966;93:282-6.

24. Stulberg DL, Clark N, Tovey D. Common hyperpigmentation disorders in adults, part II: melanoma, seborrheic keratoses, acanthosis nigricans, melasma, diabetic dermopathy, tinea versicolor, and postinflammatory hyperpigmentation. Am Fam Physician. 2003;68:1963-8.

25. Gitelson S, Wertheimer-Kaplinski N. Color of the face in diabetes mellitus; observation on a group of patients in Jerusalem. Diabetes. 1965;14:201-8.

26. Namazi MR, Jorizzo JL, Fallahzadeh MK. Rubeosis faciei diabeticorum: a common, but often unnoticed, clinical manifestation of diabetes mellitus. ScientificWorldJournal. 2010;10:70-1.

27. Paron NG, Lambert PW. Cutaneous manifestations of diabetes mellitus. Prim Care. 2000;27:371-83.

28. Reid SD, Ladizinski B, Lee K, Baibergenova A, Alavi A. Update on necrobiosis lipoidica: a review of etiology, diagnosis, and treatment options. J Am Acad Dermatol. 2013;69:783-91.

29. Mendoza V, Vahid B, Kozic H, Weibel S. Clinical and pathologic manifestations of necrobiosis lipoidica-like skin involvement in sarcoidosis. Joint Bone Spine. 2007;74:647-9.

30. Murray CA, Miller RA. Necrobiosis lipoidica diabeticorum and thyroid disease. Int J Dermatol. 1997;36:799-800.

31. Magro CM, Crowson AN, Regauer S. Granuloma annulare and necrobiosis lipoidica tissue reactions as a manifestation of systemic disease. Hum Pathol. 1996;27:50-6.

32. Peyri J, Moreno A, Marcoval J. Necrobiosis lipoidica. Semin Cutan Med Surg. 2007;26:87-9.

33. Ngo B, Wigington G, Hayes K, Huerter C, Hillman B, Adler M, et al. Skin blood flow in necrobiosis lipoidica diabeticorum. Int J Dermatol. 2008;47:354-8

34. Muller SA, Winkelmann RK. Necrobiosis lipoidica diabeticorum histopathologic study of 98 cases. Arch Dermatol. 1966;94:1-10.

35. O'Reilly K, Chu J, Meehan S, Heller P, Ashinoff R, Gruson L. Necrobiosis lipoidica. Dermatol Online. J. 2011;17:18.

36. Santos-Juanes J, Galache C, Curto JR, Carrasco MP, Ribas A, Sanchez del Rio J. Squamous cell carcinoma arising in long-standing necrobiosis lipoidica. J Eur Acad Dermatol Venereol. 2004;18:199-200.

37. Lim C, Tschuchnigg M, Lim J. Squamous cell carcinoma arising in an area of long-standing necrobiosis lipoidica. J Cutan Pathol. 2006;33:581-3.

38. Dryden M, Baguneid M, Eckmann C, Corman S, Stephens J, Solem C et al. Pathophysiology and burden of infection in patients with diabetes mellitus and peripheral vascular disease: focus on skin and soft-tissue infections. Clin Microbiol Infect. 2015;21:S27-32.

39. Bertoni AG, Saydah S, Brancati FL. Diabetes and the risk of infectionrelated mortality in the U.S. Diabetes Care. 2001:24:1044-9.

40. Gallacher SJ, Thomson G, Fraser WD, Fisher BM, Gemmell CG, MacCuish AC. Neutrophil bactericidal function in diabetes mellitus: evidence for association with blood glucose control. Diabet Med. 1995;12:916-20.

41. Papini $M$, Cicoletti $M$, Fabrizi V, Landucci $P$. Skin and nail mycoses in patients with diabetic foot. G Ital Dermatol Venereol. 2013;148:603-8.

42. Parada $H$, Veríssimo $C$, Brandão J, Nunes $B$, Boavida J, Duarte $R$, et al. Dermatomycosis in lower limbs of diabetic patients followed by podiatry consultation. Rev Iberoam Micol. 2013;30:103-8.

43. Kalra S, Chawla A. Diabetes and balanoposthitis. J Pak Med Assoc. 2016:66:1039-41.

44. Hedayati MT, Tavakoli M, Zakavi F, Shokohi T, Mofarrah R, Ansari S, et al. In vitro antifungal susceptibility of Candida species isolated from diabetic patients. Rev Soc Bras Med Trop. 2018;51:542-5

45. Suaya JA, Eisenberg DF, Fang C, Miller LG. Skin and soft tissue infections and associated complications among commercially insured patients aged 0-64 years with and without diabetes in the U.S. PLoS One. 2013:8:e60057.

46. Noviello S, Esposito I, Pascale R, Esposito S, Zeppa P. Le infezioni de piede diabetico: aspetti microbiologici. Infez Med. 2012;20:20-7.

47. Holdiness MR. Management of cutaneous erythrasma. Drugs. 2002;62:1131-41.

48. Greywal T, Cohen PR. Erythrasma: a report of nine men successfully managed with mupirocin $2 \%$ ointment monotherapy. Dermatol Online J. 2017;15:23.

49. Kluczynik CE, Mariz LS, Souza LC, Solano GB, Albuquerque FC, Medeiros CC. Acanthosis nigricans and insulin resistance in overweight 
children and adolescents. An Bras Dermatol. 2012:87:531-7.

50. Kong AS, Williams RL, Rhyne R, Urias-Sandoval V, Cardinali G, Weller $\mathrm{NF}$, et al. Acanthosis nigricans: high prevalence and association with diabetes in a practicebased research network consortium - a PRImary care Multi-Ethnic network (PRIME Net) study. J Am Board Fam Med. 2010;23:476-85

51. Higgins ST, Fremark M, Prose NS. Acanthosis nigricans: a practical approach to evaluation and management. Dermatol Online J. 2008;14:2.

52. Rasi A, Soltani-Arabshahi R, Shahbazi N. Skin tag as a cutaneous marker for impaired carbohydrate metabolism: a case-control study. Int J Dermatol. 2007;46:1155-9.

53. Shah $R$, Jindal $A$, Patel N. Acrochordons as a cutaneous sign of metabolic syndrome: a case-control study. Ann Med Health Sci Res. 2014;4:202-5

54. Touraine A. A new hereditary chain; cutaneous fibromas, diabetes, obesity. Ann Dermatol Syphiligr. 1951;78:409-16.

55. Riad H, Al Ansari H, Mansour K, Al Mannai H, Al Sada H, Abu Shaikha $\mathrm{S}$, et al. Pruritic vesicular eruption on the lower legs in a diabetic female. Case Rep Dermatol Med. 2013;2013:641416.

56. Gupta V, Gulati N, Bahl J, Bajwa J, Dhawan N. Bullosis diabeticorum: rare presentation in a common disease. Case Rep Endocrinol. 2014;2014:862912.

57. Lopez PR, Leicht S, Sigmon JR, Stigall L. Bullosis diabeticorum associated with a prediabetic state. South Med J. 2009;102:643-4.

58. Chiriac A, Costache I, Podoleanu C, Naznean A, Stolnicu S. Bullosis diabeticorum in a young child: case report of a very rare entity and a literature review. Can J Diabetes. 2017;41:129-31.

59. Keimig EL. Granuloma annulare. Dermatol Clin. 2015;33:315-29.

60. Thornsberry LA, English JC 3rd. Etiology, diagnosis, and therapeutic management of granuloma annulare: an update. Am J Clin Dermatol. 2013;14:279-90.

61. Mempel M, Musette P, Flageul B, Schnopp C, Remling R, Gachelin $\mathrm{G}$, et al. T-cell receptor repertoire and cytokine pattern in granuloma annulare: defining a particular type of cutaneous granulomatous inflammation. J Invest Dermatol. 2002:118: 957-66.

62. Gannon TF, Lynch PJ. Absence of carbohydrate intolerance in granuloma annulare. J Am Acad Dermatol. 1994;30:662-3.

63. Nebesio CL, Lewis C, Chuang TY. Lack of an association between granuloma annulare and type 2 diabetes mellitus. $\mathrm{Br} \mathrm{J}$ Dermatol. 2002;146:122-4.

64. Veraldi S, Bencini PL, Drudi E, Caputo R. Laboratory abnormalities in granuloma annulare: a case-control study. Br J Dermatol. 1997;136: 652-3.

65. Sattar MA, Diab S, Sugathan TN, Sivanandasingham P, Fenech FF. Scleroedema diabeticorum: a minor but often unrecognized complication of diabetes mellitus. Diabet Med. 1988;5:465-8.

66. Meguerditchian $C$, Jacquet $P$, Béliard $S$, Benderitter $T$, Valéro $R$, Carsuzza F, et al. Scleredema adultorum of Buschke: un under recognized skin complication of diabetes. Diabetes Metab. 2006;32:481-4.

67. Cole GW, Headley J, Skowsky R. Scleredema diabeticorum: a common and distinct cutaneous manifestation of diabetes mellitus. Diabetes Care. 1983;6:189-92.

68.Papanas N, Maltezos E. The diabetic hand: a forgotten complication? J Diabetes Complications. 2010;24:154-62.

69. Beers $\mathbf{W H}$, Ince $A$, Moore TL. Scleredema adultorum of Buschke: a case report and review of the literature. Semin Arthritis Rheum. 2006;35:355-9.

70. Dinato SL, Costa GL, Dinato MC, Sementilli A, Romiti N. Scleredema of Buschke associated with diabetes mellitus type 2: case report and review of the literature. Arq Bras Endocrinol Metabol. 2010;54:852-5.

71. Ray V, Boisseau-Garsaud AM, Ray P, Pont F, Lin L, Hélénon R, et al. Obesity persistent scleredema: study of 49 cases. Ann Dermatol Venereol. 2002;129:281-5.

72. Santiago L, Pinho A, Cardoso JC. Eruptive xanthomas: a cardinal manifestation of serious metabolic disease. Acta Med Port 2018;31:219-22.

73. Zaremba J, Zaczkiewicz A, Placek W. Eruptive xanthomas. Postepy Dermatol Alergol. 2013;30:399-402. 